\title{
Century Bonds: Debt Or Equity Securities?
}

\author{
Kam C. Chan (Email: kchan@pace.edu), Pace University \\ P.V.Viswanath (E-mail: pviswanath@pace.edu), Pace University \\ Annie Wong (E-mail: wonga@wcsu.edu), Western Connecticut State University
}

\begin{abstract}
In this study, we examine the characteristics of firms that have issued century bonds and the debtversus-equity classification of these bonds. Although it is commonly assumed that such bonds are issued for tax-avoidance purpose, an examination of firm characteristics suggests that firms have non-tax related motives in issuing century bonds. The formal structure of century bonds also suggests that century bonds are similar to debt. On the other hand, our analysis of the systematic risk of issuing firm's equity shows that century bonds are more similar to equity than to debt. Thus, ultimately, the relative importance of these three factors will have to determine whether they are to be considered debt or equity.
\end{abstract}

\subsection{Introduction}

$T$

he maturity of corporate bonds generally does not exceed 40 years. However, since Walt Disney \& Co. and Coca-Cola Co. issued their 100-year bonds in 1993, a number of firms have followed suit to issue these extra long-term bonds with a maturity of 100 years. Since interest paid by a corporation on bonds is tax deductible, the deductions can generate tax savings to the issuer.

In December 1995, the U.S. Treasury Department shocked Wall Street by advocating changes in tax laws in the 1996 federal budget that would eliminate the tax deductibility of the interest payments of corporate bonds with maturity longer than 40 years. Taking into account their long maturity, the Treasury Department argued that century bonds were issued for tax-avoidance motives and should be considered as permanent equity rather than debt. However, two Congressional Committees stated that to avoid market disruption, the effective date of any tax law changes would be that of congressional action on the proposal, rather than December 1995. Furthermore, the Congressional Committees indicated that the original tax laws should grandfather any century bond offered prior to the effective date of the new changes. Corporations and financial institutions lobbied heavily against the Treasury Department's proposal and it was defeated in 1996. The Treasury Department raised this proposal again in the 1997 federal budget but was again defeated ${ }^{1,2}$.

Besides the tax treatment issues, the debt-versus-equity classification of century bonds would also have important implications for financial analysis. Financial ratios such as the debt to equity ratio are often used in financial analysis to assess the capital structure and financial risk of a company. While century bonds are classified as liabilities in company's balance sheets, many have suggested that century bonds should be classified as equity securities when conducting financial analysis (White, Sondhi, and Fried, 1998).

The objective of this study is to examine the debt-versus-equity characteristics of century bonds. The findings of this study could provide important insights to help resolve the continuing debate regarding the debt/equity nature of century bonds. The rest of this study is organized as follows. Section II describes the sample collection process and the main characteristics of the century bonds. Section III discusses the related legal literature on security classification. Section IV examines the effect of the century bonds on the systematic risk of issuing firm's equity. Finally, concluding remarks are provided in Section V.

Readers with comments or questions are encouraged to contact the authors via email. 
TABLE 1: Distribution of Century Bonds by Issuance Year, Issue Size and Coupon

Panel A:

$\begin{array}{lc}\text { Year } & \text { Number of century bonds issued } \\ & 3 \\ 1993 & 3 \\ 1995 & 9 \\ 1996 & 23 \\ 1998 & 6 \\ \text { Total } & 44\end{array}$

Panel B:

Issuance Size

$\$ 100$ million or less $\underline{\text { Number of Bonds }}$

\$101 - 200 million 6

\$201 - 300 million

\$301 - 400 million

$\$ 401$ - 500 million

$\$ 501$ - 600 million

$\$ 601$ - 700 million

\$701 - 800 million

$\$ 801$ - 900 million

Panel C:

Bond Ratings

Aaa

Aa

A

Baa

$\mathrm{Ba}$

Panel D:

\section{Coupon Rate Range}

$<6$

Number of bonds

6.01-7.0

7.01-7.25

7.26-7.5

7.51-7.75

7.76-8.00

$>8.00$

\section{Sample Description}

A list of firms that have issued century bonds in the 1993-98 period is identified from Moody's Bond Record and Standard and Poors Bond Guide ${ }^{3}$. A total of 44 century bonds issued during the sample period are included in this study ${ }^{4}$. The distribution of firms by issuance year is presented in Panel A of table 1. Out of the 44 bonds, 38 were issued in 1996, 1997 and 1998, after the first unsuccessful attempt of the Treasury Department to change the tax deduction status of interest payments on these bonds. The distribution of issuance sizes is listed in panel B of table 1. Issuance sizes range from $\$ 100$ million to $\$ 850$ million with over half of the issues being $\$ 200$ million or less. The distribution of bond ratings is reported in panel $\mathrm{C}$ of table 1. The century bonds, in general, have good bond ratings. This is consistent with the theoretical prediction of Diamond (1991) that high quality borrowers are more likely to obtain long-term financing 5 .

The issuance announcement dates of century bonds are collected from searching the LEXIS/NEXIS database and only 13 announcements are found. The stock price reaction to the issuance announcement is examined using the market-adjusted model [Brown and Warner (1985)]. Day 0 is defined as the century bond issuance announcement date and the cumulative 3-day abnormal return from days -1 to +1 is examined. Daily returns from days -170 to -21 are used to estimate the expected abnormal return. The average cumulative 3day abnormal stock return is $0.35 \%$ and it is not statistically difference from zero $(t$-statistic $=0.461)$.

Although insignificant stock price reactions to straight debt issuance announcements are often documented in prior studies [Eckho (1986), Mikkelson and Partch (1986) and Shyam-Sunder (1991)], Chaplinsky and Hansen (1993) find significant negative stock price reactions to unanticipated straight debt issuance. Similar mixed findings were reported in prior studies concerning the stock price reactions to equity issuance announcements. For example, Mikkelson and Partch (1986) and Barclay and Litzenberger (1988) find negative stock price reactions to equity issuance announcements. However, Wruck (1989) and Hertzel and Smith (1993) find positive stock price reactions to equity issuance announcements. Given the mixed findings of the stock price reactions to debt and equity issuance announcements in the literature, there is no conclusive evidence to determine the debt versus equity classification of century bonds using the stock price reactions to the century bonds issuance announcements. Descriptions of the century bonds are collected from the 
registration statements or prospectuses filed with the Securities and Exchange Commission (SEC). The SEC filings for 39 issues were available in the Disclosure database. One common feature is that none of the century bonds have sinking fund requirements. Mitchell (1991) suggests that sinking funds are used to control for the information asymmetry problem associated with debt issuance. Since firms issuing century bonds are large firms, information asymmetry may not be high for these firms. Also, the sinking fund feature can effectively reduce the maturity of the century bonds. According to this point of view, setting up sinking funds would contradict the original intention of issuing these long-term bonds. Another important feature is that 13 of the bonds do not have an option to be redeemed by the issuing firms while the other 26 do have such an option. The most interesting feature of the century bonds is that 32 out of 39 include an option to either redeem or shorten the maturity of the century bonds if there is any change in tax laws to eliminate the tax deductibility of the interest payments of the century bonds. For the other seven century bonds that do not have such an option, six were issued in the early 1994-1996 period and one was issued in 1998 with an option to redeem the bonds at the option of the issuer. This tax event option clearly shows the importance of the tax benefits of the century bonds to the issuing firms.

\subsection{Legal Perspectives}

The question of whether a given security is to be considered debt or equity for legal purposes has a long history in the legal literature. In a now-classic article, Plumb (1971) analyzed the question, using primarily three different categories of factors to be considered: a) those involving the formal rights and remedies of creditors as distinguished from stockholders; b) those bearing on the genuineness of the intention to create a debtor-creditor relationship; and c) those bearing on the reasonableness or economic reality of that intention (the risk element).

If we consider the first issue raised by Plumb, the formal status of the century bonds is closer to debt than to equity, particularly considering the remedies available to bondholders on default. The structure of the contract that century bonds establish between the security holder and the firm is also akin to debt. The security holder is promised a certain fixed payment every six months for a certain number of years, with the face value of the bonds to be repaid at the end of those years. There does not seem to be any equity-like characteristics here; for example, century bondholders have no right to share in the upside of the firm's fortunes. In this sense, century bonds are less equity-like than, say, convertible bonds of shorter maturities, which have been held to be debt securities.

Another point arguing for century bonds to be considered as debt is the fact that the coupon rates on these bonds are fairly close to the yields on other comparable corporate bonds with more conventional maturities. For example, the average coupons on the bonds in our sample is $7.30 \%$, which is about 65 basis points higher than the average yield on 30-year bonds for the twenty-four months of 1996 and 1997, which is not far from the usual spread of AA and AAA rated bonds over the Treasury yield ${ }^{6}$. According to the survey study of Bruner, Eades, Harris and Higgins (1998), the historical equity market premium over Treasury yield is about 700 basis points and most financial advisers use this risk premium in their financial analysis. The spread of the average century bond yield over the Treasury yield is much less than the historical equity risk premium.

The next point to be investigated, following Plumb, is the intention of the parties in creating the security. For this, we need to look at financial theories that explain a firm's choice of debt maturity. We look at three different factors, two of them unrelated to taxes, and the third one being tax-related.

\subsection{Liquidity Risk and Information Asymmetry}

Studies such as Diamond (1991, 1993) and Stiglitz and Weiss (1981) suggest that firms have incentives to issue debt with longer maturity when liquidity risks and information asymmetry are low. In this study, we use the market value of a firm's equity to measure the impact of liquidity risk and information asymmetry on its debt maturity choice. Large firms tend to have lower default and liquidity risks and should be able to issue debt with long maturity to reduce the cost of refinancing. Large firms also have more publicly available information and the information asymmetry problem should be less severe for them when issuing long-term debt. Table 2 reports the comparisons between the sample firms and their industry averages for 34 firms that have sufficient firm and industry data available in Compustat. Among the sample firms, 88 percent of their market values of equity are higher than 
their industry averages. The parametric test also shows that the sample firms are in general larger than their respective industry averages in term of market capitalization. A common measure of default risk is total debt to equity ratio. For the sample firms, only about 38 percent of their total debt to equity ratios are higher than their industry average. This suggests that the sample firms have low default risk. These findings are consistent with the argument that large firms with lower liquidity risk and information asymmetry are more likely to issue debt with long maturity.

TABLE 2: Comparisons between Sample Firms and Industry Averages

\begin{tabular}{|c|c|c|c|c|c|}
\hline & $\begin{array}{l}\text { Market Value } \\
\text { of Equity }^{2}\end{array}$ & $\begin{array}{l}\text { Market- to- } \\
\text { Book Ratio }^{3}\end{array}$ & $\begin{array}{l}\text { Tax Expense } \\
\text { Ratio }^{4}\end{array}$ & $\begin{array}{c}\text { Debt- to- } \\
\text { Equity Ratio }\end{array}$ & $\begin{array}{l}\text { Long-Term Debt } \\
\text { to Total Debt }\end{array}$ \\
\hline \multicolumn{6}{|l|}{ Standardized values $^{7}$ : } \\
\hline \# Less than -1.96 & 1 & 19 & 11 & 13 & 9 \\
\hline \# Less than -1.654 & 1 & 20 & 12 & 14 & 9 \\
\hline \# Greater than 1.654 & 28 & 4 & 17 & 11 & 19 \\
\hline \# Greater than 1.96 & 28 & 4 & 17 & 10 & 17 \\
\hline \multicolumn{6}{|l|}{ Percentage Of Firms } \\
\hline \multicolumn{6}{|l|}{ With Standardized Values } \\
\hline \multicolumn{6}{|l|}{ Higher Than Their } \\
\hline Respective Industry Averages ${ }^{1}$ & $188.24^{* * *}$ & $26.59^{* * *}$ & 58.82 & $38.24 *$ & $70.59^{* * *}$ \\
\hline
\end{tabular}

Total of 34 issues for which data were available.

1. Industry classification is based on 2-digit SIC code.

2. Market value of equity is the number of common shares outstanding multiplied by closing stock price at the end of the fiscal year.

3. Market-to-book ratio is market value of common stock divided by the book value of common stock equity.

4. Tax Expense Ratio is the income taxes expense divided by total assets.

5. Debt-to-equity ratio is total debt divided by market value of equity.

6. Long-term debt to total debt is long-term debt divided by total debt.

7. Standardized values for each measure are computed as the difference between the variable value for each firm and the average for the industry, standardized by the standard deviation of values for the variable within the industry, i.e. (firm value - industry av.)/(industry s.d.).

8. ***, * Significant at the $1 \%, 10 \%$ level, respectively, based on a one-tailed binomial test assuming an equal probability of observing a value for a sample firm higher or lower than its industry average, under the null.

\subsection{Agency costs of debt}

Myers (1977) suggests that firms with high agency costs of debt have more incentives to issue short-term debt to minimize the financing costs. Guedes and Opler (1996) argue that firms with low growth opportunities have low agency costs of debt since the managers of these firms have less flexibility in term of investment decisions. The market-to-book ratio is used as a measure of the growth opportunity of firms in this study as in Guedes and Opler (1996). As reported in table 2, only 26 percent of the sample firms' market-to-book ratios are higher than their industry averages. The parametric test also suggests that the sample firms have lower market-to-book ratios than their industry averages. In addition, about 70 percent of sample firms also have higher long-term debt to total debt ratios than their industry averages. This is consistent with the argument that firms with low growth opportunity and agency costs of debt tend to issue long-term debt.

\subsection{Tax Benefits}

Tax benefits have often been suggested as one of the major reasons for firms to issue long-term debt. Since the term structure of debt is upward sloping, firms with greater expected benefits from debt tax shields have more incentive to issue debt with longer maturity. Table 2 also reports the sample firms' tax expense ratios compared to their industry averages. The analysis shows that only about 58 percent of the sample firms have higher tax expense ratios than their industry average. Neither the binomial and parametric tests provide much evidence that the sample 
firms have higher tax expense ratios than their industry averages. Hence, there is little support for the IRS argument that the long maturity of the century bonds was chosen primarily to evade corporate taxes.

From the point of view of the first two factors identified by Plumb, then, one could argue that century bonds are more properly classified as debt than equity.

\subsection{The riskiness of century bonds}

The third and last major factor that Plumb takes up is the issue of risk. This was stated much earlier, as well, in United States v. Title Guarantee \& Trust Co. ${ }^{7}$

The essential difference between a stockholder and a creditor is that the stockholder's intention is to embark upon the corporate adventure, taking the risks of loss attendant upon it, so that he may enjoy the chances of profit. The creditor, on the other hand, does not intend to take such risks so far as they may be avoided, but merely to lend his capital to others who do intend to take them.

How risky are century bonds? Clearly, given the long maturity of these bonds, the risk taken by the bondholders is much greater than a holder of a bond with maturity of thirty years or less in terms of greater sensitivity of the bond value to changes in bond yield. On the other hand, even a century bondholder has priority over stockholders in the return of capital. If the intention were to create a security which was nominally a bond, but which was effectively equity-like, it would have made more sense for riskier firms to issue these bonds, raising the risk of non-payment of principal. Although one might analyze corporate securities from these different points of view, it must be acknowledged it is ultimately difficult to determine whether a particular security is debt or equity. In fact, Plumb (1976) says "courts are at liberty to arrive at opposite results on identical facts depending upon their own whims as to which factors they wish to stress." (quoting Weis; 1962).

In the next section, we further look at the question of the riskiness of century bonds, by examining their systematic risk relative to that of equity and conventional debt.

\section{The Systematic Risk of Century Bonds}

The empirical model used in this section is based on the theoretical models of Hamada (1972) and Bowman (1979). These two models suggest that the systematic risk of a firm's assets is a weighted average of the systematic risk of equity and the systematic risk of debts.

$$
\beta_{\text {assets }}=(\mathrm{E} / \mathrm{V}) \beta_{\text {equity }}+(\mathrm{D} / \mathrm{V}) \beta_{\text {debt, }}
$$

where $\beta_{\text {assets }}$ is the systematic risk of a firm's assets, $\beta_{\text {equity }}$ and $\beta_{\text {debt }}$ are the systematic risk of the firm's equity and debt respectively; $\mathrm{E}$ is the market value of the firm's equity, $\mathrm{D}$ is the market value of the firm's debt, and $\mathrm{V}$ is the sum of market values of debt and equity. The above equation can be rearranged as:

$$
\beta_{\text {equity }}=\beta_{\text {assets }}+(\mathrm{D} / \mathrm{E})\left(\beta_{\text {assets }}-\beta_{\text {debt }}\right)
$$

If the beta of total debt is a weighted-average of the beta of century bonds and the beta of other debt excluding century bonds, we can rearrange equation (2) to separate century bonds from the other debts of a firm as follows:

$\beta_{\text {equity }}=\beta_{\text {assets }}+(\mathrm{DXCB} / \mathrm{E})\left(\beta_{\text {assets }}-\beta_{\text {other_debt }}\right)+(\mathrm{CB} / \mathrm{E})\left(\beta_{\text {assets }}-\beta_{\mathrm{cb}}\right)$,

where DXCB is total liabilities excluding the century bond, CB is the amount of century bonds, $\beta_{\text {other_debt }}$ is the beta of other debt excluding century bonds, and $\beta_{\mathrm{cb}}$ is the beta of century bonds. If century bonds are considered the same as other liabilities by investors, $\beta_{\text {other_debt }}$ should be the same as $\beta_{\mathrm{cb}}$. Since $\left(\beta_{\text {assets }}-\beta_{\text {other_debt }}\right)$ is greater than zero, $\left(\beta_{\text {assets }}-\beta_{\mathrm{cb}}\right)$ should also be greater than zero. On the other hand, if century bonds are considered to be

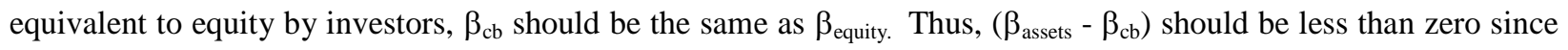
$\beta_{\text {equity }}$ is greater than $\beta_{\text {assets. }}$ The empirical model suggested by (3) is: 
$\beta_{\mathrm{i}}=\mathrm{b}_{0}+\mathrm{b}_{1}\left(\mathrm{DXCB}_{\mathrm{i}} / \mathrm{E}_{\mathrm{i}}\right)+\mathrm{b}_{2}\left(\mathrm{CB}_{\mathrm{i}} / \mathrm{E}_{\mathrm{i}}\right)+$ error

where

$\beta_{\mathrm{i}} \quad=$ systematic risk of equity of firm $I$

$\mathrm{DXCB}_{\mathrm{i}} / \mathrm{E}_{\mathrm{i}}=$ total firm liabilities excluding century bonds divided by the market value of the common stock of firm $i$

$\mathrm{CB}_{\mathrm{i}} / \mathrm{E}_{\mathrm{i}} \quad=$ book value of century bonds divided by the market value of common stock of firm $I$

If the market behavior of century bonds is similar to that of debt securities, $b_{1}$ in model (4) should be positive. On the other hand, the $b_{2}$ coefficients should be negative if the risk characteristics of the century bonds are closer to those of equity securities. The systematic risk of each firm is estimated by regressing the daily stock returns of each firm on the returns of the Standard \& Poors' 500 Index. The daily stock returns of the fiscal year following the issuance of century bond are used in the estimation. The book value rather than market value of total liabilities and century bonds are used because of the unavailability of their market values. ${ }^{8}$

Data for 39 century bond issuers was available for the regression analysis. The average book value of century bond as a percentage of the book value of total debt is 3.5\%. The average book value of century bonds as a percentage of the sum of the total book value of all debt and the market value of equity is $1.3 \%$. If century bonds were reclassified from debt to equity, the average debt to equity ratio would change from 1.272 to 1.206 and the difference is statistically significant at one percent level based on a two-tailed $t$-test of the difference of means.

The results of the regression analysis are reported in Table 3. The coefficient estimate of $b_{1}$ in model (4) is positive as expected and it is statistically significant at the $1 \%$ level. The coefficient estimate of $b_{2}$ is negative and statistically significant at the $1 \%$ level. The negative $\mathrm{b}_{2}$ coefficient implies that the risk characteristics of century bonds are closer to those of equity securities than debt securities.

TABLE 3: Summary of Regression Results

\begin{tabular}{|c|c|c|c|}
\hline \multicolumn{4}{|c|}{ Model : $\beta_{\mathrm{i}}=\mathrm{b}_{0}+\mathrm{b}_{1}\left(\mathrm{DXCBt}_{\mathrm{i}} / \mathrm{E}_{\mathrm{i}}\right)+\mathrm{b}_{2}\left(\mathrm{CB}_{\mathrm{i}} / \mathrm{E}_{\mathrm{i}}\right)$} \\
\hline Coefficient & Parameter Estimate & $t$-statistic & Prob $>|t|$ \\
\hline $\mathrm{b}_{0}$ & 0.94052 & 14.33 & 0.0010 \\
\hline$b_{1}$ & 0.08633 & 3.49 & 0.0013 \\
\hline$\underline{\mathrm{b}}_{2}$ & -9.29362 & -4.67 & 0.0001 \\
\hline \multicolumn{4}{|c|}{ Adjusted $\mathrm{R}^{2}=0.3990$} \\
\hline \multicolumn{4}{|c|}{$\begin{array}{l}\beta_{\mathrm{i}} \quad=\text { systematic risk of equity of firm } i \\
\mathrm{DXCB}_{\mathrm{i}} / \mathrm{E}_{\mathrm{i}}=\text { total firm liabilities excluding century bonds divided by the market value of the common } \\
\text { stock of firm } i\end{array}$} \\
\hline
\end{tabular}

\section{Concluding Remarks}

Many innovative securities have been issued in recent years that have characteristics of both debt and equity. One of these securities is bond with a 100-year maturity. The U.S. Treasury Department has argued that century bonds are used by corporations to issue tax-deductible equity, and would deny them tax deductions for interest paid on these securities. The classification of century bonds as either debt or equity also has important implications for financial analysis purposes. In this study, we examine the characteristics of firms that have issued century bonds and the debt-versus-equity features of these bonds. An examination of firm characteristics suggests that their intentions are not primarily to maximize tax benefits. For example, our sample firms generally have higher market capitalization and lower market-to-book ratios than their respective industry averages, which is 
predicted by theories of debt maturity. On the other hand, an examination of the systematic risk of century bonds shows them to be much more similar to equity than to debt.

In conclusion, it would seem that century bonds are formally similar to debt and that century-bond issuers seem to have non-tax related motives. However, from a risk point of view, they are closer to equity. Thus, ultimately, the relative importance of these three factors will have to determine whether they are to be considered debt or equity.

\section{Suggestions for Future Research}

Besides century bonds, there are many other hybrid securities with both debt and equity features. Finnerty and Emery (2002) provides a comprehensive review of many innovative securities and some of these securities have both debt and equity characteristics. Future study may examine the issuance motives and valuation issues of these innovative securities.

\section{References}

1. Brealey, R., and S. Myers, Principles of Corporate Finance, Fourth Edition, McGraw-Hill, 1991.

2. Bowman, R., "The theoretical relationship between systematic risk and financial variables," Journal of Finance (June): 617-629, 1979.

3. Brown, S.J., and J.B. Warner, "Using daily stock returns: The case of event studies," Journal of Financial Economics 14, 3-31, 1985.

4. Bruner, R., K. Eades, R. Harris, and R. Higgins, "Best practices in estimating the cost of capital: Survey and synthesis," Financial Practice and Education (Spring/Summer): 13-28, 1998.

5. Chaplinsky, S. and R. Hansen, "Partial anticipation, the flow of information and the economic impact of corporate debt sales," The Review of Financial Studies (Vol.6): 709-732, 1993.

6. Diamond, D., "Debt maturity structure and liquidity risk," Quarterly Journal of Economics: 709-737, 1991.

7. Diamond, D., "Seniority and maturity of debt contracts," Journal of Financial Economics: 341-368, 1993.

8. $\quad$ Eckho, B., "Valuation effects of corporate debt offerings," Journal of Financial Economics (Jan/Feb): 119$152,1986$.

9. Finnerty, John D and Emery, Douglas R., "Corporate Securities Innovation: An Update," Journal of Applied Finance, Volume 12, Spring/Summer: 21-47, 2002.

10. Guedes, J., and T. Opler, "The determinants of the maturity of corporate debt issues," Journal of Finance (December): 1809-1833, 1996.

11. Hamada, R., "The effects of the firm's capital structure on the systematic risk of common stocks," Journal of Finance (May): 435-452, 1972.

12. Hariton, David P., "Distinguishing Between Equity and Debt in the New Financial Environment," The New York University Tax Law Review, Spring, 49 Tax L. Rev. 499., 1994.

13. Hertzel, M. and R. Smith, "Market discounts and shareholder gains for placing equity privately," Journal of Finance (March): 459-485, 1992.

14. Kover, A., "Credit crush," Fortune, New York, December 7:254-255, 1998.

15. Litzenberger, R., and C. Rao, "Portfolio theory and industry cost of capital estimates," Journal of Financial and Quantitative Analysis: 1443-1462, 1972.

16. Mikkelson W. and M. Partch, "Valuation effects of security offerings: An empirical investigation," Journal of Financial Economics (Jan/Feb): 91-118, 1986.

17. Mitchell, K., "The call, sinking fund, and term-to-maturity features of corporate bonds: An empirical investigation," Journal of Financial and Quantitative Analysis: 201-222, 1991.

18. Myers, S., "Determinants of corporate borrowing," Journal of Financial Economics (November): 147-175, 1977.

19. Pesck, W., "Current yield: Bond returns, dismal all year, aren't likely to perk up soon," Barron's (December 13): MW9, 1999.

20. Plumb, William T., "The Federal Tax Significance of Corporate Debt: A Critical Analysis and a Proposal," Tax Law Review, v. 26, pp. 369-640, 1971. 
21. Polito, Anthony P., "Useful Fictions: Debt and Equity Classification in Corporate Tax Law," Arizona State Law Journal, v. 30, p. 761 ff, 1998.

22. Shyam-Sunder, L., "The stock price effect of risky versus safe debt," Journal of Financial and Quantitative Analysis (December): 549-558, 1991.

23. Stiglitz, J. and A. Weiss, "Credit rationing in markets with imperfect information," American Economic Review: 393-411, 1981.

24. White, G., Sondhi, A., and Fried, D., The analysis and use of financial statements, Second Edition, Wiley, 1998.

25. Wruck, K., "Equity ownership concentration and firm value: Evidence from private equity financings," Journal of Financial Economics (23): 3-28, 1989.

\section{Endnotes}

1. The New York Times of February 7, 1997 ran an article entitled "Encore for '96 Plan to Hike Taxes on Business." Here is an except from the article:

The budget plan also tries to clarify a long-standing dispute over the distinction between debt and equity, which the tax code treats differently but which have become increasingly blurred with the large volumes of bonds with maturities of more than 40 years and zero coupon convertible debt. If the proposals were adopted, the law would treat those products as equities, rather than bonds, eliminating favorable tax treatment.

2. In fact, there is a history of unsuccessful administrative and legislative attempts to determine the definition of debt and equity securities. Polito (1998) summarizes the unsuccessful efforts of Congress (in 1954) to itself define debt and equity, followed in 1969 by a mandate to the Treasury to come up with a definition. The Treasury, in 1980 and 1982, did issue rules purporting to allow one to distinguish between debt and equity, but faced with the issue of a security called the adjustable rate convertible note (ARCN) which would have passed the rules for being considered debt, but which had a high probability, nevertheless, of being converted into equity, backed off and returned to a case-by-case determination.

3. Given the global credit crisis and the expectation of raising interest rate in the late 90 s, there were little interest among investors and issuers for long-term debt [Kover (1998) and Pesek (1999)]. Thus, no century bond is identified for 1999 and 2000.

4. There is one firm that issued century bonds in two different nonconsecutive years. The two bond issues are treated as two observations in the sample. There are two firms that each issued more than one century bond in the same year. Only the first bond is included in the sample.

5. The bond ratings in panel $\mathrm{C}$ are based on Moody's bond rating system. The bond ratings for four century bonds are obtained from Standard and Poors and these bond ratings are stated in the equivalent Moody's ratings.

6. See Table 1, Panel D. Since almost all century bonds were issued very closed to their par value, the bond coupon rate is used as a proxy for bond yield. 30-year Treasury bond yields obtained from the Bridge Commodity Research series, available from http://www.economagic.com. According to data presented by Damodaran (2000) for February 1999 from http://www.bondsonline.com, the average spread over the 30year Treasury bond rate is 20 basis points for AAA bonds, 50 basis points for AA bonds and 80 basis points for $\mathrm{A}+$ rated bonds.

7. 133 F.2d 990, 993 ( $6^{\text {th }}$ Cir. 1943), cited in Hariton (1994).

8. Preferred stock is not included as debt or equity in the analysis since preferred stock is often considered as having characteristics of both debt and equity. 